Received $\quad 19.03 .2018$

Reviewed $\quad 16.07 .2018$

Accepted 20.08.2018

A - study design

B - data collection

C - statistical analysis

D - data interpretation

$\mathbf{E}$ - manuscript preparation

F - literature search

\section{Water quality and microbial contamination status of groundwater in Jaffna Peninsula, Sri Lanka}

\author{
M.G.Y.L. MAHAGAMAGE 1) ABCDEF , Pavithrani S. MANAGE ${ }^{2) \text { BF }}$ \\ Pathmalal M. MANAGE ${ }^{3)}$ ABD $₫$
}

\footnotetext{
1) orcid.org/0000-0002-7406-0423; University of Sri Jayewardenepura, Department of Zoology, Centre for Water Quality and Algae Research, Gangodawila, Nugegoda 10250, Sri Lanka; e-mail: m.g.y.l.mahagamage@gmail.com

${ }^{2)}$ Eastern University, Faculty of Health Care Sciences, Vantharumoolai, Chenkalady, Sri Lanka; e-mail: sadupamamanage@gmail.com

3) orcid.org/0000-0002-2014-2060; University of Sri Jayewardenepura, Department of Zoology, Nugegoda, Sri Lanka;

e-mail: pathmalal@sjp.ac.lk
}

For citation: Mahagamage M.G.Y.L., Manage P.S., Manage P.M. 2019. Water quality and microbial contamination status of groundwater in Jaffna Peninsula, Sri Lanka. Journal of Water and Land Development. No. 40 (I-III) p. 3-12. DOI: 10.2478/jwld-2019-0001.

\begin{abstract}
In Sri Lanka, among 2588 Salmonella positive cases, the highest incidences were recorded from Jaffna peninsula during 2005 to 2013. Therefore, the present study aimed to identify the microbiological and chemical contamination status of groundwater (40 well water) sources in Jaffna during November 2016. The total coliform, E. coli, Salmonella spp. and Shigella spp. along with some physico-chemical parameters of groundwater were studied. The results revealed that entire peninsula was contaminated with total coliform and E. coli bacteria and the parameters recorded were not within the WHO and SLS (Sri Lanka Standards) drinking water quality standards. 38\% of sampling locations were positive for Salmonella spp. and among them six sampling locations were being used for drinking purposes. The results of the study correlates with the statistics of typhoid cases recorded in Jaffna. Results of the study also revealed that around $80 \%$ of wells were not within the values specified in guidelines of the SLS for drinking water quality on electrical conductivity. Further, $15 \%$ of wells recorded greater than $10 \mathrm{mg} \cdot \mathrm{dm}^{-3}$ nitrate, which is still below the SLS drinking water standards $\left(45 \mathrm{mg} \cdot \mathrm{dm}^{-3}\right)$. According to the water quality data, PCA analysis showed that Jaffna town, Nallur, Tellippalai and Kopay DS divisions has similar characteristics for water quality.
\end{abstract}

Key words: coliform, E.coli, groundwater, Jaffna Peninsula, Salmonella spp., Shigella spp., water quality

\section{INTRODUCTION}

Groundwater is a most vital natural resource for life due to its purity and availability [VERMA et al. 2013] and plays a significant role for drinking, industry, agriculture and domestic sectors [MAHAGAMAGE, MANAGE 2015]. In Sri Lankan context, most part of the country around $60 \%$ people extract groundwater for drinking from shallow dug wells [MENR, UNEP 2009] and its annual availability for consumption is around 7800 million $\mathrm{m}^{3}$ [MENR, UNEP 2009]. The Jaffna Peninsula is located in the Northern Province of Sri Lanka and surface and running water sources such as rivers, streams and springs are not availa- ble. According to the Asian Development Bank, 53,600 protected wells, 8,800 unprotected wells and 5,100 tube wells are recorded in Jaffna district by 2010, and these wells are distributed all over the rural and semi-urban areas in Jaffna, mostly as private wells associated with single family homesteads [VILLHOLTH, RAJASOORIYAR 2010].

Jaffna Peninsula is an agrarian area which cultivate and produces different types of commercial crops such as vegetables, red onions, tobacco, chilies, grapes and bananas, etc., and agriculture is the main source of livelihood for $65 \%$ of the population [THADCHAYINI, THIRUCHELVAM 2005]. JEYARUBA and THUSHYANTHY [2009] reported that farmers use high amount of organic and green manures, 
inorganic fertilizers and agrochemicals for their crop without a knowledge in fertilizer requirement for plants. Thus, high nitrate concentrations in well water were recorded in the area [SUTHARSINY et al. 2014] and it is very likely related to the intensive cultivation practices [VITHANAGE et al. 2014]. Based on the limited availability of drinking water sources, number of studies have been conducted to evaluate the suitability of well water for drinking in Jaffna by means of physico-chemical parameters [HIDAYATHULLA, KARUNARATNA 2013; JEYARUBA, THUSHYANTHY 2009; KUMARA et al. 2013] and limited records are available on total coliform and $E$ coli contamination and no inventory on Shigella spp. and Salmonella spp. contamination in well water [ARULNESAN et al. 2015]. Waterborne infections are common and widespread when clean water and sanitation are not in satisfactory level [HUNTER 1997] and cause waterborne gastrointestinal diseases outbreaks [CRAUN et al. 2006]. According to the World Health Organization (WHO) two and a half billion people have no access to quality portable water and more than 1.5 million children die each year from diarrheal diseases [FENWICK 2006] and 3.4 million people, mostly children, die from water-related diseases [WHO 2003b]. Salmonellosis and Shigellosis are the most common and widely distributed waterborne and foodborne diseases in worldwide and usually characterized by acute onset of fever, diarrhea, abdominal pain, nausea and vomiting [CHALKER, BLASER 1988]. HUNTER [1997] stated that mainly developing countries in Asia and African continent suffer from gastro intestinal diseases due to consumption of contaminated water and a number of studies have shown that the Salmonella and Shigella contamination was significant in sewage effluents, freshwater, marine waters and well water with poor sanitary practices [ADB 2010; MAHAGAMAGE et al. 2016a, b, c; MANNAPPERUMA et al. 2013]. Accordingly, the Health Ministry statistics of Sri Lanka from 2005 to 2013 revealed that among 2588 Salmonella positive cases, the highest incidences were recorded from Jaffna Peninsula.

Therefore, evaluation of water quality and epidemiological data in Jaffna Peninsula is of high contemporary importance and the Asian Development Bank [ADB 2010] highlighted the importance of the study on water quality and priority was given to Jaffna Peninsula to focus on pathogenic bacteria contamination in well water as groundwater is the only drinking water source for human consumption in Jaffna. Hence, the present study focused to evaluate the microbiological contamination status of well water in Jaffna Peninsula by means of total coliform, E. coli, Salmonella spp., Shigella spp. along with hydrochemical qualities.

\section{MATERIALS AND METHODS}

\section{STUDY AREA}

The Jaffna District covers an area of $1,023 \mathrm{~km}^{2}$ and contains low percentage of surface water sources due to its karstic nature, the terrain of the peninsula is flat and it reaches the highest elevation of $10.5 \mathrm{~m}$ [DISSANAYAKE, SENARATNE 1981]. Accordingly, shallow karst aquifer type wells are located beneath by Miocene limestone formations which are generally from $100 \mathrm{~m}$ to $150 \mathrm{~m}$ thick [PANABOKKE 2007]. Further, karstic aquifer is mainly dispersed across the western half of the peninsula and its outer islands, the eastern half of the peninsula beyond Point Pedro and Chavakachcheri is mainly made up of sandy regosols on recent beach and dune sands, which supports a different type of aquifer. The soil of the Peninsula varies from welldrained and highly productive red yellow latosols in the central area $(60,000 \mathrm{ha})$; alkaline, saline regosol soils in the coastal area (26,000 ha); and alluvial soils in the Valukki Aru area (10,000 ha) [MIKUNTHAN et al. 2013].

\section{WATER SAMPLING}

Water samples were collected from forty wells including dug wells, tube wells and agro-wells in the Jaffna Peninsula during November 2016 (Tab. 1, Fig. 1). Pre-cleaned

Table 1. Groundwater sampling locations in the Jaffna Peninsula during the study

\begin{tabular}{|c|c|c|}
\hline Sample & Location & Usage \\
\hline 1 & Point Pedro & agro well \\
\hline 2 & Nervelli & drinking \\
\hline 3 & Kalviyankadu & drinking \\
\hline 4 & Jaffna Town & drinking \\
\hline 5 & Kokuvil & drinking \\
\hline 6 & Maruthanarmadam & agro well \\
\hline 7 & Thelipalli & agro well \\
\hline 8 & Kadduvan & \begin{tabular}{|l|} 
drinking \\
\end{tabular} \\
\hline 9 & Shanguveli & agro well \\
\hline 10 & Annakodi & drinking \\
\hline 11 & Nainathivu & drinking \\
\hline 12 & Nainathivu & drinking \\
\hline 13 & Nainathivu & drinking \\
\hline 14 & \begin{tabular}{|l|} 
Pungudutivu \\
\end{tabular} & \begin{tabular}{|l|} 
salt water \\
\end{tabular} \\
\hline 15 & Pungudutivu North & salt water \\
\hline 16 & Velanai west & salt water \\
\hline 17 & Velanai North & salt water \\
\hline 18 & Mulai & salt water \\
\hline 19 & Kattudi & drinking \\
\hline 20 & Annakodi & not drinking \\
\hline 21 & Kalviyankadu & drinking \\
\hline 22 & Kopay & drinking \\
\hline 23 & Vannar panni & drinking \\
\hline 24 & Kokuvil & drinking \\
\hline 25 & Urumpirai & drinking \\
\hline 26 & Thirunelvely & agro well \\
\hline 27 & Maruthanarmadam & agro well \\
\hline 28 & Mallagam & drinking \\
\hline 29 & Mavitapuram & drinking \\
\hline 30 & Palai & drinking \\
\hline 31 & Putter & drinking \\
\hline 32 & Pulloli & drinking \\
\hline 33 & Point Pedro & drinking \\
\hline 34 & Kodikamam & drinking \\
\hline 35 & Sittali & agro well \\
\hline 36 & Nervelli & drinking \\
\hline 37 & Delft (Nadukuruchi) & agro well \\
\hline 38 & Delft & drinking \\
\hline 39 & Delft (Saraiti) & drinking \\
\hline 40 & Delft & drinking \\
\hline
\end{tabular}

Source: own elaboration. 


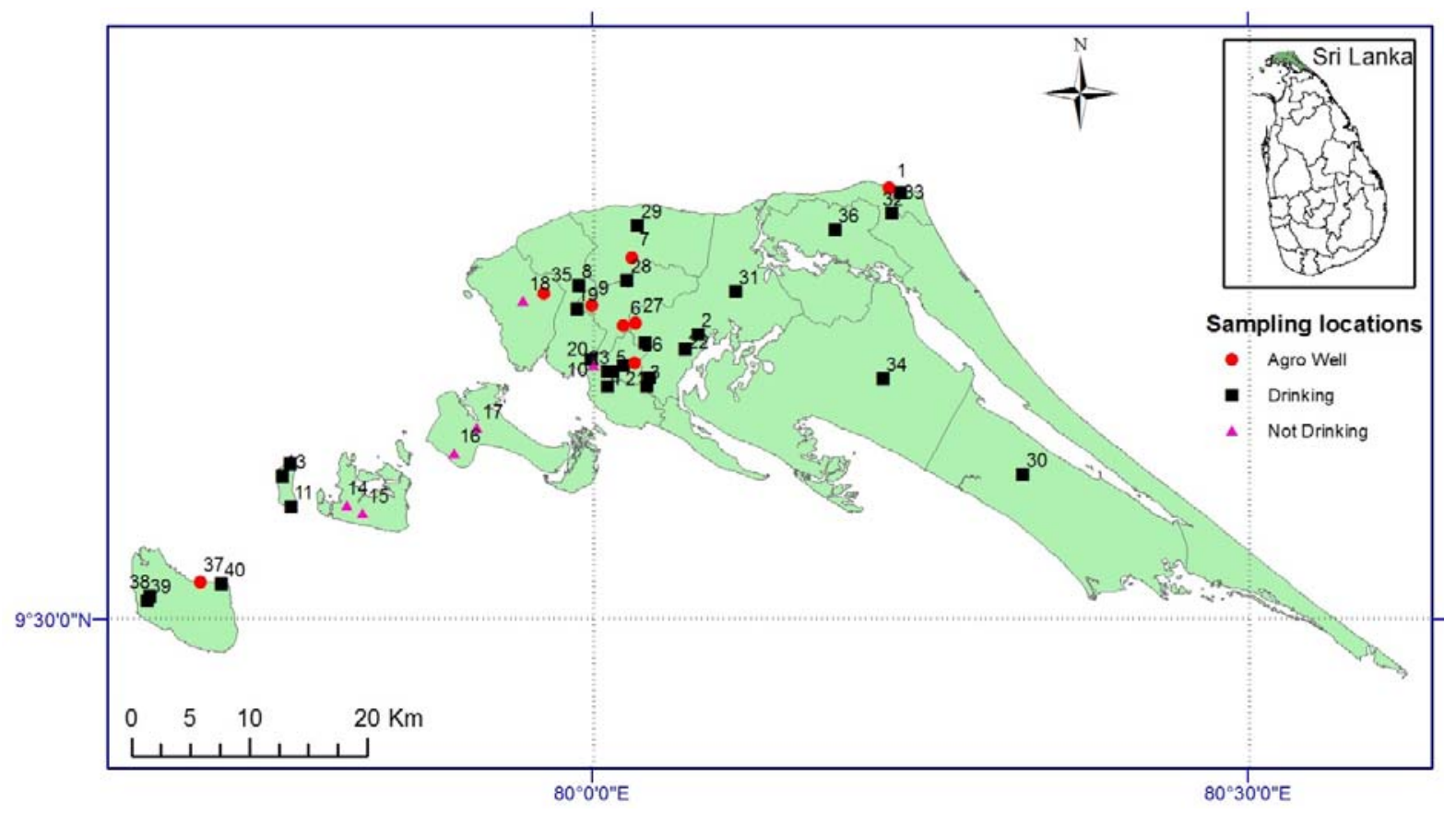

Fig. 1. Ground water sampling locations in the Jaffna Peninsula during the study; source: own elaboration

polypropylene bottles and amber colour sterile glass bottles were used to collect water for chemical and microbial analysis respectively $[\mathrm{MOH} 2010]$. Water samples were transported to the laboratory in a refrigerated condition within 24 hours and stored in a cold room. Microbiological and chemical analyses were performed within 24 hours after the collection of samples. The GPS coordinates were recorded via a hand-held Garmin eTrex 30 GPS receiver at the site.

\section{PHYSICO-CHEMICAL ANALYSIS}

Water temperature, dissolved oxygen (DO) and $\mathrm{pH}$ parameters were measured using a HQD portable multimeter (HACH - HQ 40D) and total dissolved solids (TDS), electrical conductivity $(E C)$ and salinity were recorded using a portable conductivity meter $(\mathrm{HACH}-$ Sension EC5) at the site itself. Chemical oxygen demand (COD) was determined by using the closed reflux method where ammonia (as $\mathrm{N}-\mathrm{NH}_{3}$ ), nitrates (as $\mathrm{N}-\mathrm{NO}_{3}$ ), nitrite (as $\mathrm{N}-\mathrm{NO}_{2}$ ) and total phosphate (TP) concentrations were measured by the Spectrophotometric (Spectro UV-VIS Double UVD 2960) methods. Total hardness was determined by using the titrimetric method with EDTA following the standard method [APHA 1999].

\section{MICROBIOLOGICAL ANALYSIS}

\section{Total and fecal coliform bacteria (membrane filtration} method)

Membrane Lactose Glucuronide Agar (MLGA) Membrane Filtration method was performed to determine the Total coliform (TC) and E. coli count per $0.1 \mathrm{dm}^{3}$ of the water samples. Samples were filtered through $0.45 \mu \mathrm{m}$ filter papers (Whatman Cat No: 7001 0004, D-47mm) and then the filter papers were kept on the MLGA plates and incubated at $37^{\circ} \mathrm{C}$ for $18 \pm 2$ hours [SLSI 2013].

\section{Identification of Salmonella spp. and Shigella spp.}

26 samples were subjected to identification of pathogenic Salmonella spp. and Shigella spp. $1 \mathrm{dm}^{3}$ of sample was filtered through $0.45 \mu \mathrm{m}$ filter papers (Whatman Cat No: $70010004, \mathrm{D}-47 \mathrm{~mm}$ ) and then the filter paper was dipped in the sterile $0.09 \mathrm{dm}^{3}$ buffered peptone water and incubated at $37^{\circ} \mathrm{C}$ for $18 \pm 2$ hours. After incubation, enriched broth (BPW) was inoculated to selective enrichment media. $0.001 \mathrm{dm}^{3}$ of enrichment broth was added into 0.01 $\mathrm{dm}^{3}$ of Rappaport Vassiliadis soya peptone broth (RVS) and incubation was followed at $41.5^{\circ} \mathrm{C}$ for $24 \pm 3$ hours and $0.001 \mathrm{dm}^{3}$ of enrichment broth into $0.01 \mathrm{dm}^{3}$ of selenite cystine broth (SCB) was incubated at $37^{\circ} \mathrm{C}$ for $24 \pm 3$ hours. After the selective enrichment, colonies were isolated by streak plating onto Salmonella-Shigella agar (SSA) and Xylose lysine deoxycholate agar (XLD) then the plates were incubated at $37^{\circ} \mathrm{C}$ for $24 \pm 3$ hours. Suspected colonies of Salmonella spp. and Shigella spp. were identified by using colony appearances. Further, identification of suspected colonies of Salmonella spp. and Shigella spp. were performed by biochemical tests; Kligler Iron Agar (KIA) test, urea test, lysine decarboxylation test, indole test and motility test following standard protocol [HPA 2006; 2007; SLCM 2011].

\section{STATISTICAL ANALYSIS}

The dataset was processed using the Minitab (version 15) statistical software. Principal Component Analysis was carried out for 14 physico-chemical and microbiological parameters along with depth of 40 groundwater sampling locations. 


\section{GIS THEMATIC MAPPING}

Collected data of groundwater quality in the whole Jaffna Peninsula was stored in a geographic information system (GIS) database. These data were digitized with a Sri Lanka survey department digital map created in 1999 at 1:50 000 scale. The inverse distance weighted interpolation (IDW) under spatial analyst tool in the ArcGIS 10.0 software was employed for interpretation of data.

\section{RESULTS AND DISCUSSION}

\section{GROUNDWATER QUALITY}

The spatial distribution pattern of water quality parameters in well water of the study area is shown in Figure 2.
$\mathrm{pH}$ is one of the most important water quality parameter, and the optimum required $\mathrm{pH}$ in drinking water is often being in the range between 6.5 to 9.5 [WHO 2004]. According to Sri Lankan drinking water standards, the highest desirable level for $\mathrm{pH}$ range is $7.0-8.5$ where the maximum permissible level is $6.5-8.5$. In the present study, the minimum and maximum values of $\mathrm{pH}$ in groundwater were 6.55 and 8.72 respectively, and the values remained within the WHO and SLS maximum permissible level, but not within the highest desirable level for SLS water quality standards. Spatial distribution pattern of $\mathrm{pH}$ in the study area is given in Figure 2c which shows high $\mathrm{pH}(<7.5)$ at Delft and Nainathivu (Nagadeepa) islands, which may due to aquifer type of the island is limestone with some unconsolidated brown [GOONATILAKE et al. 2013].
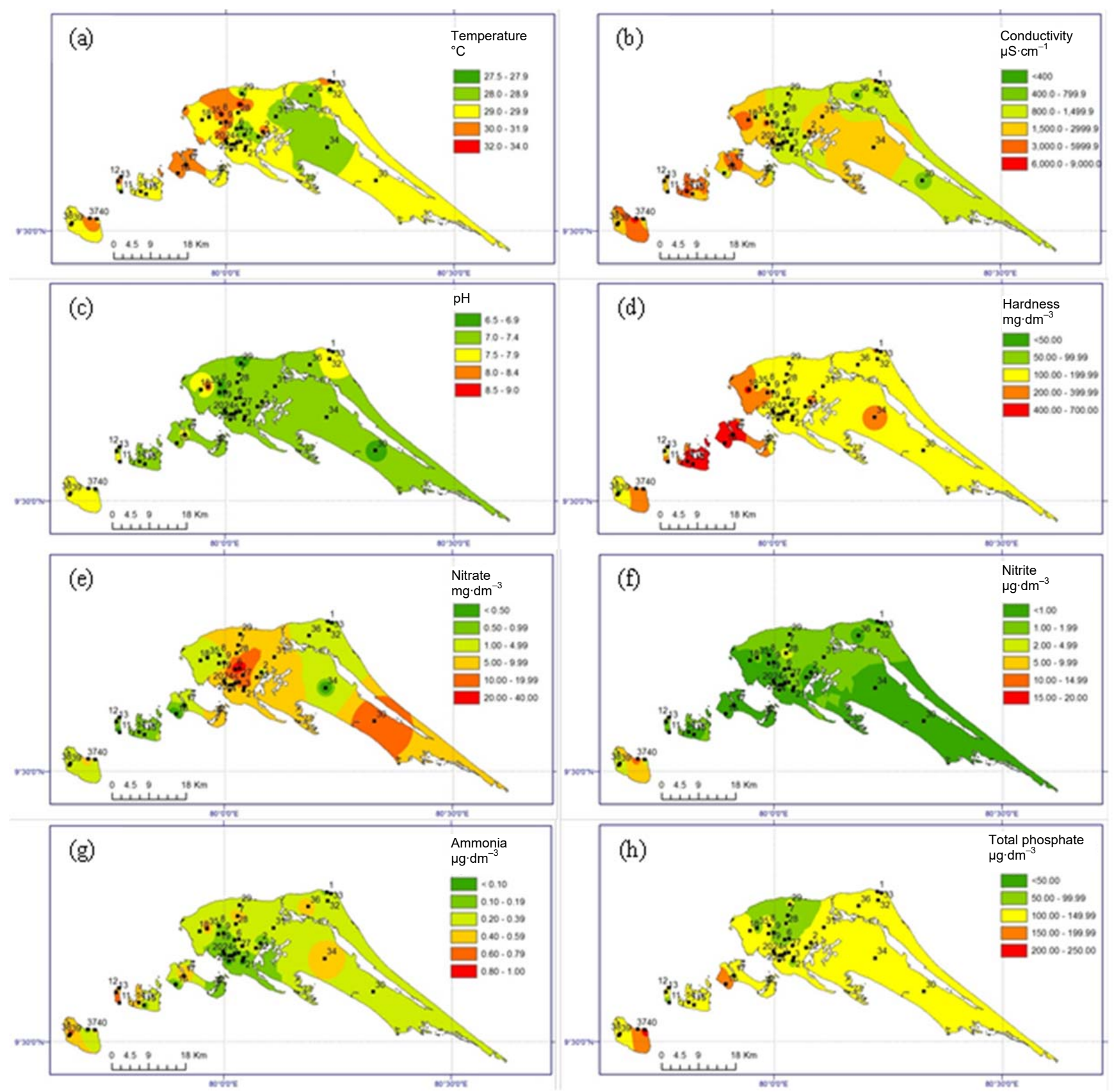


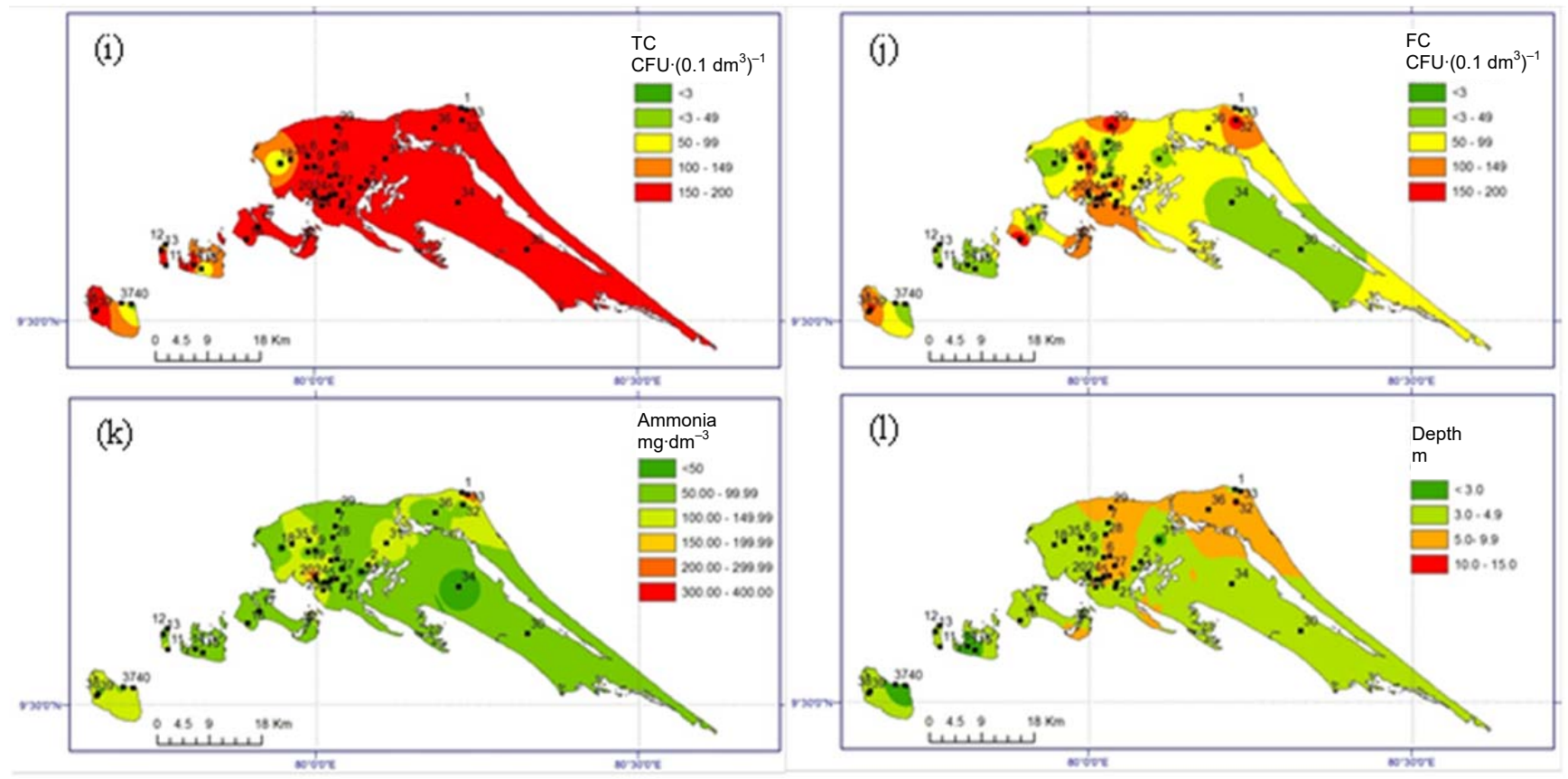

Fig. 2. Spatial distribution of a) temperature, b) electrical conductivity, c) $\mathrm{pH}$, d) hardness, e) nitrate (as $\left.\left.\mathrm{N}-\mathrm{NO}_{3}\right), \mathrm{f}\right)$ nitrite $\left(\right.$ as $\mathrm{N}-\mathrm{NO}_{2}$ ), g) ammonia (as $\mathrm{N}^{-\mathrm{NH}_{3}}$ ), h) total phosphate (TP), i) total coliform (TC), j) faecal coliform (FC), k) COD, l) depth of well; source: own study

Electrical conductivity $(E C)$ is a parameter related to total dissolved solids (TDS) and salinity. $E C$ is comprised of inorganic salts (principally calcium, magnesium, bicarbonates, chlorides, potassium, sodium, nitrates and sulphates) and small amounts of organic matter that are dissolved in water [NAS, BERKTAY 2010]. According to the Sri Lankan water quality standards, $750 \mu \mathrm{S} \cdot \mathrm{cm}^{-1}$ is the recommended value for $E C$. It was found that that $80 \%$ of groundwater samples exceeded the recommended guideline values of $E C$ for drinking water in Sri Lanka (750 $\mu \mathrm{S} \cdot \mathrm{cm}^{-1}$ ) and WHO standards [KUMARA et al. 2013]. The highest $E C$ was recorded $\left(8523 \mu \mathrm{S} \cdot \mathrm{cm}^{-1}\right)$ from Delft Island and this may due to the saline water intrusion into shallow aquifers (Fig. 2b). TDS and salinity of well water was ranged between $227.4-5369.4 \mathrm{mg} \cdot \mathrm{dm}^{-3}$ and $162.4-3835.3$ $\mathrm{mg} \cdot \mathrm{dm}^{-3}$, respectively. JoshuA et al. [2013] documented similar results for TDS and stated that the coastal wells are dominated by the high content of sodium chloride in sea water and these wells probably intercept the transition zone with brackish water. In the study some dug wells marked as $6,7,9,25,30,32,35,36,40$ are in isolated pockets and showed low $E C\left(<750 \mu \mathrm{S} \cdot \mathrm{cm}^{-1}\right)$ - Figure $2 \mathrm{~b}$.

Water hardness results from the contact of groundwater with rock formations [EMMANUEL et al. 2013]. Hardness is due to the presences of polyvalent metallic ions, predominantly $\mathrm{Ca}^{2+}$ and $\mathrm{Mg}^{2+}$ [EMMANUEL et al. 2013] and is normally expressed as the total concentration of calcium and magnesium ions in water units of $\mathrm{mg} / \mathrm{l}$ as equivalent $\mathrm{CaCO}_{3}$ [Dissanayake, ChandRaJith 2009]. $\mathrm{Ca}$ and $\mathrm{Mg}$ are present as simple ions $\mathrm{Ca}^{2+}$ and $\mathrm{Mg}^{2+}$ with the Ca levels varying from tens to hundreds of $\mathrm{mg} \cdot \mathrm{dm}^{-3}$ and the $\mathrm{Mg}$ concentrations varying from units of tens of $\mathrm{mg} \cdot \mathrm{dm}^{-3}$ [Dissanayake, ChandRajith 2009]. The sources of the metallic ions are limestone $\left(\mathrm{CaCO}_{3}\right)$ and dolomite $\left(\mathrm{CaMg}\left(\mathrm{CO}_{3}\right)_{2}\right)$ and soils of the Jaffna Peninsula are formed on marine deposits and sediments under the effect of sea waves and wind; a thin mantle of soils with a thickness of less than $2 \mathrm{~m}$ was found above the limestone rock resulting hard water nature. Hardness in water is mainly due to dissolved compounds of calcium and magnesium and by a variety of other metals [USGS 2016]. It is usually expressed as the equivalent quantity of calcium carbonate [WHO 2004]. According to general guidelines for classification of waters are considered as: soft $\left(0\right.$ to $\left.60 \mathrm{mg} \cdot \mathrm{dm}^{-3}\right)$; moderately soft/moderately hard (61 to $120 \mathrm{mg} \cdot \mathrm{dm}^{-3}$ ); hard $\left(121\right.$ to $\left.180 \mathrm{mg} \cdot \mathrm{dm}^{-3}\right)$ and very hard $\left(>180 \mathrm{mg} \cdot \mathrm{dm}^{-3}\right)$ according to the concentration of calcium carbonate [USGS 2016].

KOBAYASHI [1957] showed a relationship between water hardness and the incidence of vascular diseases. Other studies reported the existence of a relationship between cardiovascular disease mortality and water hardness [EMMANUEL et al. 2013]. Nonetheless, a large number of studies covering many countries suggest such a correlation [Dissanayake, ChandRaJITH 2009]. RUBENOWITZ-LuNDIN and HISCOCK [2013] have documented that very hard natural water with $\mathrm{CaCO}_{3}$ concentration higher than 200 $\mathrm{mg} \cdot \mathrm{dm}^{-3}$ with a magnesium concentration lower than $7 \mathrm{mg} \cdot \mathrm{dm}^{-3}$ may affect various organs including the cardiovascular physiology. Further, the acidity of the water influences the reabsorption of calcium and magnesium in the renal tubule [SENGUPTA 2013]. However, public acceptability of the hardness may differ from one community to another depending on residential background. The results of the present study showed hardness of water in the Jaffna was ranged between 45.33 to $611.33 \mathrm{mg} \cdot \mathrm{dm}^{-3}$ and the highest value was recorded from Velanai North $(611.33$ $\mathrm{mg} \cdot \mathrm{dm}^{-3}$ ) Figure 2d. Except one sampling location, rests were having hard or very hard water according to USGS [2016]. Higher hardness values were recorded at certain islands (i.e., Velanai $\left(611.33 \mathrm{mg} \cdot \mathrm{dm}^{-3}\right)$, Delft $(394.0$ $\left.\mathrm{mg} \cdot \mathrm{dm}^{-3}\right)$, Nainathivu $\left(312.0 \mathrm{mg} \cdot \mathrm{dm}^{-3}\right)$ and Pungudutivu 
$\left(556.0 \mathrm{mg} \cdot \mathrm{dm}^{-3}\right)$ where peninsula water hardness values were remained comparatively low. Thus, the results of the present study showed 93\% sampling locations have greater than $100 \mathrm{mg} \cdot \mathrm{dm}^{-3}$ of water hardness where $23 \%$ of wells exceeded the concentration greater than the SLS drinking water guideline value $\left(250 \mathrm{mg} \cdot \mathrm{dm}^{-3}\right)$. This may due to conversion of insoluble bicarbonates into soluble carbonates with existence of carbon dioxide in soil [NAS, BERKTAY 2010].

In general nitrate concentration in groundwater of Sri Lanka is low but water leaching through surface to ground water via soil, through agricultural lands, human and animal waste result high concentration of nitrate in ground water [WHO 2004]. During recent years, the groundwater contamination by nitrate has been documented all over the world [FytIANOS, CHRISTOPHORIDIS 2004] and Jaffna Peninsula [SUTHARSINY et al. 2014; VITHANAGE et al. 2014]. The health concerns about consumption of high nitrate and nitrite contaminated water and its significant health impact due to formation of methemoglobinemia causing blue baby syndrome was well documented in different parts of the world [NAS, BERKTAY 2010; WHO 2004]. The spatial distributions pattern of nitrate levels in the present study is given in Figure 2e and it was ranged between 0.01 to 38.51 $\mathrm{mg} \cdot \mathrm{dm}^{-3}$. The highest nitrate concentration was recorded $\left(38.51 \mathrm{mg} \cdot \mathrm{dm}^{-3}\right)$ in an agro well, which is located near to Maruthanarmadam. Nitrate concentration in $15 \%$ of sampling locations in the study exceeded the WHO drinking water quality guideline value $\left(10 \mathrm{mg} \cdot \mathrm{dm}^{-3}\right)$, although the concentrations remained below the guideline values given by SLS (SLS614, $1983\left(45 \mathrm{mg} \cdot \mathrm{dm}^{-3}\right)$ for drinking water. More or less similar results were recorded by the SUTHARSINY et al. [2014] as well for Jaffna water. Interestingly, $63 \%$ of agro wells recorded greater than $7 \mathrm{mg} \cdot \mathrm{dm}^{-3}$ of nitrate, which may due to the intensive agricultural practices within and around the area. NAGARAJAH et al. [1988] reported the use of organic manure from cattle, goats and inorganic fertilizers along with agrochemicals are high around the area where high nitrate was reported, and thus, leaching of excess fertilizers into the shallow aquifers through soil could be a major reason. However, the results of the study showed that $88 \%$ of drinking water wells were within the WHO and SLS drinking water guidelines for nitrate, and only three sampling locations at Annakodi $\left(10.0 \mathrm{mg} \cdot \mathrm{dm}^{-3}\right)$, Kalviyankadu $\left(11.8 \mathrm{mg} \cdot \mathrm{dm}^{-3}\right)$ and Palai $\left(15.8 \mathrm{mg} \cdot \mathrm{dm}^{-3}\right)$ exceeded the concentration recommended for human drinking water by WHO. Inadequate distance between toilet pits and drinking water wells may also have been a significant factor responsible for high nitrate in ground water [GUNASEKARAM 1983]. Present results showed a clear relationship between the distance of toilet pit ( $<20$ feet) and dug well with high contamination of nitrate. Thus, the site geology and soil type in Jaffna Peninsula are considerable geological factors that affect the ground water quality in terms of nitrate contamination [RAJASOORIYAR et al. 2002]. Although nitrate is the major form in which nitrogen occurs in groundwater, there is also dissolved nitrogen in the form of ammonia and nitrite [FREZE, CHERRY 1979]. Ammonia and nitrite concentrations in groundwater of the study area ranged from $<0.10$ to $0.82 \mu \mathrm{g} \cdot \mathrm{dm}^{-3}$ and from $<1.00$ to $15.22 \mu \mathrm{g} \cdot \mathrm{dm}^{-3}$ respectively. The highest values of ammonia and nitrite were detected at Delft island (Fig. 2f, g), where only one sampling location (Delft - Nadukuruchi: $15.2 \mu \mathrm{g} \cdot \mathrm{dm}^{-3}$ ) was exceeded the guideline value of nitrite (SLS614, $1983<10$ $\mu \mathrm{g} \cdot \mathrm{dm}^{-3}$ ) and the other wells were remained within the SLS drinking water guideline value for ammonia (60 $\left.\mu \mathrm{g} \cdot \mathrm{dm}^{-3}\right)$.

The total phosphorous (TP) concentration in groundwater is normally low as phosphates are moderately soluble [FADIRAN et al. 2008]. However, concentration of phosphate can increase in groundwater as a result of agricultural or anthropological activities. In the present study, it was found that TP concentration ranged between 32.36 to $240.55 \mu \mathrm{g} \cdot \mathrm{dm}^{-3}$ and the highest concentration recorded at Delft Island (Fig. 2h). Interestingly, 73\% sampling locations exceeded TP concentration greater than $100 \mu \mathrm{g} \cdot \mathrm{dm}^{-3}$ and still the concentrations are far below the SLS guideline value for TP $\left(2000 \mu \mathrm{g} \cdot \mathrm{dm}^{-3}\right)$.

The coliform count is used as an indicator of treatment efficiency, sanitation and the reliability of the water supply systems. Escherichia coli (E. coli), is one species of the coliform group, which is always found in faeces [WHO 1997]. Therefore, the present study focused on total coliform (TC) and E. coli count in the groundwater to evaluate quality of water for human consumption as a critical factor. The results indicate that the entire peninsula was contaminated with both total coliform and $E$. coli bacteria. $85 \%$ and $23 \%$ of wells recorded greater than $200 \mathrm{CFU} \cdot\left(0.1 \mathrm{dm}^{3}\right)^{-1}$ - for TC and E. coli, respectively (Fig. 2i, j). Similar results were recorded by ARULNESAN et al. [2015] and present study recorded that the majority $(90 \%)$ of public water sources in peninsula was microbiologically unsatisfactory. Further, coliforms are indicators of existence of microorganisms, which show pollution of water and the possibility of having disease-causing organisms. Considering the fact, present study specially focused on pathogenic bacterial contamination of groundwater in the peninsula.

Typhoid or enteric fever is a universal infection caused by the bacterium Salmonella enterica, subspecies enterica serotype Typhi, and contracted by ingestion of contaminated water [COLOMBA et al. 2006]. The Jaffna District is divided into 11 Medical Offices of Health divisions [MOH 2013]. More than half of cases relates to Enteric fever (51\%) are from 5 districts in Sri Lanka (Jaffna, Colombo, Vavuniya, Nuwara-Eliya and Badulla) and the highest incidences were recorded from the Jaffna district (2588 incidents from 2005 to 2013) [PALIHAWADANA 2015]. The results of this study revealed that $38.4 \%$ sampling locations were positive for Salmonella spp. and among them, six sampling locations were strictly used for drinking. PALIHAWADANA [2015] documented that from 2013 to 2014, 1579 typhoid cases were reported in Sri Lanka and out of 1579 cases, $28.4 \%$ typhoid cases (448) were reported from the Jaffna district; and it was the highest typhoid cases recorded in Sri Lanka. The distance between toilet pits and drinking water sources are again inferred as the possible reason.

As per the Asian Development Bank [ADB 2010], many Asian cities suffer from poor sewerage networks and 
Table 2. Occurrence of Salmonella spp. and Shigella spp. in groundwater of Jaffna Peninsula

\begin{tabular}{|c|l|c|c|c|}
\hline $\begin{array}{c}\text { Sample } \\
\text { number }\end{array}$ & \multicolumn{1}{|c|}{ Location } & $\begin{array}{c}\text { Distance to } \\
\text { toilet pit (m) }\end{array}$ & $\begin{array}{c}\text { Salmonella } \\
\text { spp. }\end{array}$ & $\begin{array}{c}\text { Shigella } \\
\text { spp. }\end{array}$ \\
\hline 12 & Nainathivu & NR & N & N \\
\hline 13 & Nainathivu & 3.0 & $\mathrm{P}$ & $\mathrm{N}$ \\
\hline 14 & Pungudutivu & 4.0 & $\mathrm{P}$ & $\mathrm{N}$ \\
\hline 15 & Pungudutivu North & 4.6 & $\mathrm{~N}$ & $\mathrm{~N}$ \\
\hline 16 & Velanai west & 5.5 & $\mathrm{P}$ & $\mathrm{N}$ \\
\hline 17 & Velanai North & 1.8 & $\mathrm{~N}$ & $\mathrm{~N}$ \\
\hline 18 & Mulai & $\mathrm{NR}$ & $\mathrm{N}$ & $\mathrm{N}$ \\
\hline 19 & Kattudi & 2.4 & $\mathrm{~N}$ & $\mathrm{~N}$ \\
\hline 20 & Annakodi & 3.0 & $\mathrm{~N}$ & $\mathrm{~N}$ \\
\hline 21 & Kalviyankadu & 1.2 & $\mathrm{P}$ & $\mathrm{N}$ \\
\hline 22 & Kopay & 1.4 & $\mathrm{P}$ & $\mathrm{N}$ \\
\hline 23 & Vannar panni & 6.1 & $\mathrm{P}$ & $\mathrm{N}$ \\
\hline 24 & Kokuvil & 6.1 & $\mathrm{~N}$ & $\mathrm{~N}$ \\
\hline 25 & Urumpirai & 6.1 & $\mathrm{~N}$ & $\mathrm{~N}$ \\
\hline 26 & Thirunelvely & $\mathrm{NR}$ & $\mathrm{P}$ & $\mathrm{N}$ \\
\hline 27 & Maruthanarmadam & $\mathrm{NR}$ & $\mathrm{N}$ & $\mathrm{N}$ \\
\hline 28 & Mallagam & 9.1 & $\mathrm{~N}$ & $\mathrm{~N}$ \\
\hline 29 & Mavitapuram & 2.4 & $\mathrm{P}$ & $\mathrm{N}$ \\
\hline 30 & Palai & 1.5 & $\mathrm{~N}$ & $\mathrm{~N}$ \\
\hline 31 & Putter & 2.1 & $\mathrm{~N}$ & $\mathrm{~N}$ \\
\hline 32 & Pulloli & 3.4 & $\mathrm{~N}$ & $\mathrm{~N}$ \\
\hline 33 & Point Pedro & 1.2 & $\mathrm{P}$ & $\mathrm{N}$ \\
\hline 34 & Kodikamam & 1.5 & $\mathrm{~N}$ & $\mathrm{~N}$ \\
\hline 37 & Delft - Nadukuruchi & $\mathrm{NR}$ & $\mathrm{P}$ & $\mathrm{N}$ \\
\hline 38 & Delft & $\mathrm{NR}$ & $\mathrm{N}$ & $\mathrm{N}$ \\
\hline 39 & Delft & $\mathrm{NR}$ & $\mathrm{N}$ & $\mathrm{N}$ \\
\hline
\end{tabular}

Explanations: $\mathrm{NR}=$ not recorded $\mathrm{N}=$ negative, $\mathrm{P}=$ positive.

Source: own study.

wastewater treatment systems; and a majority of them still depends on on-site sanitation facilities. The results of this present study revealed that the majority of the households in the Jaffna area have their toilet pits close to their own dug well (Tab. 2) and around $74 \%$ of the selected wells have only a minimum distance between the toilet pit and the groundwater source well that is less than $4.6 \mathrm{~m}$ which is below the recommended distance $(16 \mathrm{~m})$ given by the PHI manual, Sri Lanka [Ministry of Health Public Health Services 2010]. Dug wells in Thirunelvely and Delft - Nadukuruchi wells that are used for agricultural activities were found positive for Salmonella spp. NAGARAJAH et al. [1988] and You et al. [2006] documented that the use of high levels of organic manure from cattle and goats for cultivation can be a possible route cause to contaminate groundwater by pathogenic Salmonella spp. in Jaffna area. Further, pathogenic contamination may occur due to the nature of the geographical soil of the area as well. According to the PANABOKKE and PERERA [2005] Jaffna is favourable for groundwater pollution, with limestone as the main aquifer which has no purification capacity.

Chemical oxygen demand (COD) is a measure of the capacity of water to consume oxygen during the decomposition of organic matter and the oxidation of inorganic chemicals such as ammonia and nitrite, and is widely used to determine the amounts of organic pollutants level in water. In the present study, COD concentration ranged between 8.98 to $303.46 \mathrm{mg} \cdot \mathrm{dm}^{-3}$ and the highest concentration recorded from Point Pedro $\left(303.46 \mathrm{mg} \cdot \mathrm{dm}^{-3}\right)$. Almost all sampling points were not within the guidelines value $\left(10 \mathrm{mg} \cdot \mathrm{dm}^{-3}\right)$ given by the SLS and WHO for drinking water. HASKONING and KONSULT [1989] showed that human faeces and urine contribute to more COD in water. Considering the results on distance between toilet pits and drinking water wells, it was found that majority of dug wells were situated in a distance less than $6.1 \mathrm{~m}$ from the toilet pits in most of the sampling locations. Thus, the distance between toilet pits and wells may be a possible major reason to detect high concentrations of COD in groundwater in Jaffna Peninsula (Fig. 2k).

\section{STATISTICAL ANALYSIS}

Principal component analysis (PCA) is a nonparametric method of classification, which generally used for reducing the dimensions of multivariate problems without loss of information given by the study [MAHAGAMAGE et al. 2015]. To determine the correlation between both locations and water quality parameters, PCA was performed. PCA results showed that Jaffna, Nallur, Tellippalai and Kopay DS divisions have similar water quality characteristics with regard of water quality and the same DS divisions showed high concentration of nitrate and TC count (Fig. 3). In addition, Nainathive and Chunnakam DS divisions also have been grouped by PCA analysis. Nainathive locations showed high values of ammonia, $\mathrm{pH}, \mathrm{DO}$ and temperature during the study period and Chunnakam agro wells were found to be high in E. coli count. The loading plot is indicating correlation between conductivity, TDS, salinity, hardness and nitrite where locations 14,17 and 18 showed high values for the mentioned parameters as well.

\section{CONCLUSIONS}

The primary objective of the present study was to evaluate groundwater quality in Jaffna Peninsula along with its pathogenic contamination status. The results indicate that the entire peninsula was contaminated with total coliform, E. coli and $38 \%$ sampling locations were positive for Salmonella spp., and among them six sampling locations were used for drinking purposes. The microbiological data of the present study is highly correlated with typhoid cases recorded previously by $\mathrm{MOH}$ data. $35 \%$ of sampling locations showed high hard water quality (more than 180 $\mathrm{mg} \cdot \mathrm{dm}^{-3}$ ) according to USGS [2016] classification. Majority of the sampling locations were not within the drinking water quality standards given for COD by SLS and WHO (SLS $6142013-10 \mathrm{mg} \cdot \mathrm{dm}^{-3}$ ). In approximately $15 \%$ sampling locations, greater nitrate concentration (10 $\mathrm{mg} \cdot \mathrm{dm}^{-3}$ ) was recorded. However, the recorded nitrate levels are still below the values given for drinking water by the SLS (SLS614 $1983-45 \mathrm{mg} \cdot \mathrm{dm}^{-3}$ ). According to the water quality data, PCA analysis showed that Jaffna town, Nallur, Tellippalai and Kopay DS divisions has similar characteristics for water quality. Results revealed that proper management plan is necessary to save groundwater resources of the Jaffna Peninsula along with implementing awareness programs and rules and regulations for water pollution. 


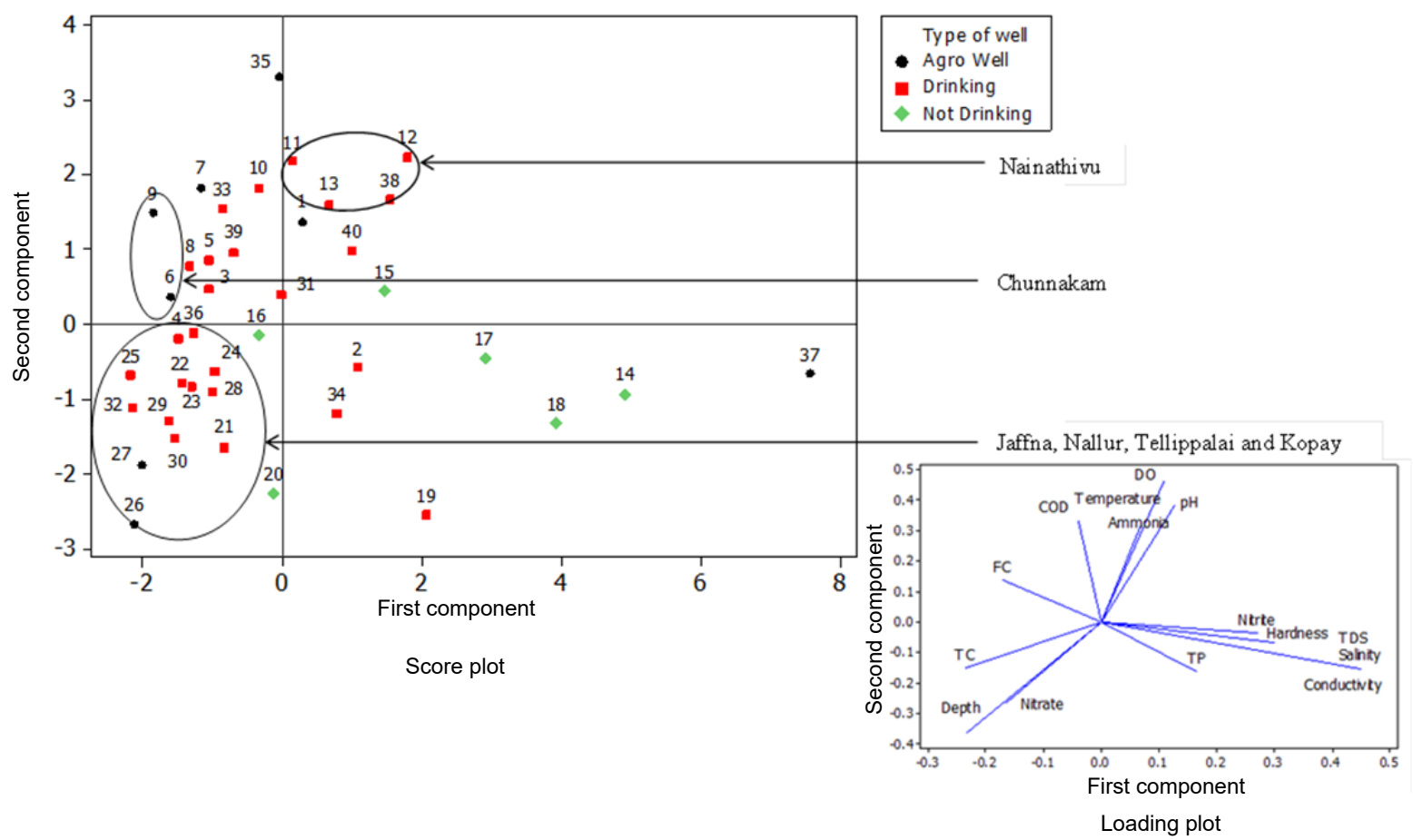

Fig. 3. Score plot and loading plot derived from PCA analysis; source: own study

\section{REFERENCES}

ADB 2010. Democratic Socialist Republic of Sri Lanka: Jaffna and Kilinochchi water supply and sanitation project. Initial Environmental Examination. RRP SRI 37378. Asian Development Bank. [Access 11.01.2017]. Available at: https:// www.adb.org/sites/default/files/linked-documents/37378-01sri-ieeab.pdf

APHA 1999. Standard methods for examination of water and waste water. 20th ed. Washington, DC. American Public Health Association pp. 541.

ARUlnesan C.A., Kamsan S., RaJeshKannan N., SivaPalan K., Murugananthan K. 2015. Contaminated public well water as a source of sporadic outbreak of enteric infection in Northern Sri Lanka. Sri Lankan Journal of Infectious Diseases. Vol. 5. Iss. 2 p. 64-72. DOI 10.4038/sljid.v5i2.8090.

Chalker R.B., Blaser M.J. 1988. A review of human salmonellosis: III. Magnitude of Salmonella infection in the United States. Review of Infectious Diseases. Vol. 10. Iss. 1 p. 111 124.

Colomba C., SAPorito L., Infurnari L., Tumminia S., Titone L. 2006. Typhoid fever as a cause of opportunistic infection: Case report. BioMed Central Infectious Diseases. Vol. 6. Iss. 1 pp. 38.

Craun M.F., Craun G.F., Calderon R.L., Beach M.J. 2006. Waterborne outbreaks reported in the United States. Journal of Water and Health. Vol. 4. Iss. 2 p. 19-30.

Dissanayake C.B., ChandRajith R. 2009. Introduction to medical geology. Dordrecht Heidelberg, London, New York. Springer. ISBN 978-3-642-10150-2 pp 297.

Dissanayake C.B., Senaratne A. 1981. Paleogeographical reconstruction of Jaffna Peninsula. Journal of the Geological Society of India. Vol. 23 p. 369-377.

Emmanuel E., Simon Y., Joseph O. 2013. Characterization of hardness in the groundwater of Port-au-Prince. An overview on the health significance of magnesium in the drinking water. Aqua-LAC. Vol. 5. Iss 2 p. 35-43.
FAdiran A.O., Dlamini S.C., Mavuso A. 2008. A comparative study of the phosphate levels in some surface and ground water bodies of Swaziland. Bulletin of the Chemical Society of Ethiopia. Vol. 22. Iss. 2 p. 197-206.

FENWICK A. 2006. Waterborne diseases - could they be consigned to history? Science. Vol. 313 p. 1077-1081.

FreEZE R.A. ChERRY J.A. 1979. Groundwater. Englewood Cliffs, NJ. Prentice-Hall. Inc. ISBN 0133653129 pp. 604.

Fytianos K., Christophoridis C. 2004. Nitrate, arsenic and chloride pollution of drinking water in Northern Greece: Elaboration by applying GIS. Environmental Monitoring and Assessment. Vol. 93. Iss. 1-3 p. 55-67.

GoOnatilake S.D.A., Ekanayake S., Kumara T.P., LiyanaPATHIRANA D., WEERAKOON D.K., WADUGODAPITIYA A. 2013. Sustainable development of Delft Island: An ecological, socio-economic and archaeological assessment. Occasional Papers of IUCN Sri Lanka. No. 014. Colombo. IUCN. ISBN 978-955-0205-18-9 pp. 86.

GUNASEKARAM T. 1983. Groundwater contamination and case studies in Jaffna Peninsula, Sri Lanka. Colombo, Sri Lanka. Water Resources Board.

HASKONING, M-KONSUlt 1989. Study on solid waste management and pollution caused by sewerage systems in Dar-esSalaam. Dar-es-Salaam, Tanzania. Ministry of Water pp. 90.

Hidayathulla M.S.M., KarunaRATna G.R.R. 2013. Assessment of groundwater quality in shallow aquifers in Jaffna Peninsula. Proceedings to 29th Technical Sessions of Geological Society of Sri Lanka Peradeniya. GSSL p. 109-113.

HPA 2006. Detection of Salmonella species. Health Protection Agency. National Standard Method. Vol. 7. Iss. 3. [Access 28.05.2014]. Available at: http://www.hpa-standardmethods. org.uk/pdf_sops.asp

HPA 2007. Detection of Shigella species in water. Health Protection Agency. National Standard Method. Vol. 8. Iss. 3. [Access 28.05.2014]. Available at: http://www.hpastandardmethods.org.uk/pdf_sops.asp 
HUNTER P.R. 1997. Waterborne diseases: Epidemiology and ecology. Chichester, UK. John Wiley \& Sons. ISBN 978-0471-96646-3 pp. 384.

Jeyaruba T., ThuShyanthy M. 2009. The effect of agriculture on quality of groundwater: A case study. Middle-East Journal of Scientific Research. Vol. 4. Iss. 2 p. 110-114.

Joshua W.D., Thushyanthy M., NANTHAGOBAn N. 2013. Seasonal variation of water table and groundwater quality of the karst aquifer of the Jaffna Peninsula-Sri Lanka. Journal of the National Science Foundation of Sri Lanka. Vol. 41. Iss. 1 p. 3-12.

KoBAYASHI J. 1957. On geographical relations between the chemical nature of river water and death rate from apoplexy. Berichte des Ohara Instituts für landwirtschaftliche Biologie, Okayama Universität. Vol. 11. Iss. 1 p. 12-21.

Kumara I., Rathnayaka S., Mayadunne M., Rajapakse R. 2013. Assessment of groundwater quality in Jaffna Peninsula. Journal of Geological Society of Sri Lanka. Vol. 15 p. 137146.

Mahagamage M.G.Y.L., Pathirage S., Manage P.M. 2016a. Seasonal variation in abundance of pathogenic bacteria in surface water of the Kelani River basin, Sri Lanka. International Conference on Multidisciplinary Approaches (ICMA) 2016. Faculty of Graduate Studies, University of Sri Jayewardenepura, Sri Lanka p. 5.

Mahagamage M.G.Y.L., Pathirage S., Manage P.M. $2016 \mathrm{~b}$. Microbiological quality in ground water of the Kelani River basin, Sri Lanka. 25th Annual Scientific Session of the Sri Lanka College of Microbiologists p. 28-29.

Mahagamage M.G.Y.L., Pathirage S., Manage P.M. $2016 \mathrm{c}$. Occurrence of pathogenic bacteria and water quality of the surface water in the Kelani river basin, Sri Lanka. Proceedings of the 22th annual scientific sessions of the Sri Lanka Association for Fisheries and Aquatic Resources p. 27.

Mahagamage M.G.Y.L., Manage P.M. 2015. Mapping spatial distribution of water quality parameters of groundwater in the Kelani river basin using GIS. 12th International Conference on Environmental Science and Development (ICESD), Singapore p. 10-14.

Mahagamage M.G.Y.L., Chinthaka S.D.M., Manage P.M. 2015. Multivariate analysis of physico-chemical and microbial parameters of surface water in Kelani river basin. International Journal in Multidisciplinary Studies (IJMS). Vol. 1. Iss. 1 p. 55-61.

Mannapperuma W.M.G.C.K., Abayasekara C.L., Herath G.B.B., Werellagama D.R.I.B. 2013. Potentially pathogenic bacteria isolated from different tropical waters in Sri Lanka. Water Science and Technology: Water Supply. Vol. 13. Iss. 6 p. 1463-1469. DOI 10.2166/ws.2013.143.

MENR, UNEP 2009. Sri Lanka Environment Outlook 2009. Battaramulla. Ministry of Environment and Natural Resources and United Nations Environment Programme. ISBN 978-9550033-10-2 pp. 154.

Ministry of Health Public Health Services 2010. Manual for the Sri Lanka Public Health Inspector (PHI Manual). Chapter 2. Environmental Health, State Printing Corporation, Padukka. ISBN 978-955-0505-00-5 p. 79-131.

Mikunthan T., Vithanage M., Pathmarajah S., Arasalingam S., Ariyaratne R., Manthrithilake H. 2013. Hydrogeochemical characterization of Jaffna's aquifer systems in Sri Lanka. International Water Management Institute (IWMI). pp. 69. DOI 10.5337/2014.001.

MOH 2010. Collection, storage, and transport of samples for investigation. In: Manual for the Sri Lanka Public Health Inspector. Chapter 8. Ministry of Health Public Health Services p. $275-284$.
MOH 2013. Enteric fever. P. I. Weekly Epidemiological Report. Vol. 40 Iss. 43. [Access 24.01.2017]. Available at: http://www.epid.gov.lk/web/images/pdf/wer/2013/vol_40_no 43 english.pdf.

Nagarajah S., Emerson B.N., Abeykoon V., Yogalingam S. 1988. Water quality of some wells in Jaffna and Kilinochchi with special reference to nitrate pollution. Tropical Agriculturist. Vol. 144 p. 61-73.

NAS B., BERKTAY A. 2010. Groundwater quality mapping in urban groundwater using GIS. Environmental monitoring and assessment. Vol. 160. Iss. 1-4 p. 215-227.

Palihawadana P. 2015. Typhoid vaccination situation in Sri Lanka [online]. Ministry of Health, Sri Lanka. [Access 24.01.2017]. Available at: http://www. coalitionagainsttyphoid.org/wp-content/uploads/2015/05/ 8.35-8.50-AM-Palihawadana.-Typhoid Vaccination_Final.pdf

Panabokke C.R., Perera A.P.G.R.L. 2005. Groundwater resources of Sri Lanka. Colombo, Sri Lanka. Water Resources Board p. 3-11.

PANABOKKE C.R. 2007. Groundwater conditions in Sri Lanka. A geographic perspective. Colombo, Sri Lanka. National Science Foundation. ISBN 9555900795 pp. 149.

RAJASOORIYAR L., Mathavan V., DHARMAGUnAwardHANE H.A., NANDAKumar V. 2002. Groundwater quality in the Valigamam region of the Jaffna Peninsula, Sri Lanka. In: Sustainable groundwater management. Eds. K.M. Hiscock, M.O. Rivett, R.M. Davison. Geological Society of London. Vol. 193 p. 181-197.

RuBENOWITZ-Lundin E., Hiscock K.M. 2013 Essentials of medical geology. In: Water hardness and health effects. Dordrecht-Heidelberg-New York-London. Springer p. 337-350.

SENGUPTA P. 2013. Potential health impacts of hardwater. International Journal of Preventive Medicine. Vol. 4. Iss. 8 p. 866-875.

SLCM 2011. Laboratory Manual in Microbiology. $2^{\text {nd }}$ ed. Colombo. Sri Lanka College of Microbiologists. ISBN 9788891-03-2 pp. 230.

SLSCI 2013. Microbiological test methods for water. Part 1 Detection and enumeration of Escherichia coli and Coliform bacteria - Section 2 - Reference method, SLS 1461 Part 1 Section 3. Colombo. Sri Lanka Standards Institution.

Sutharsiny A., Manthrithilake H., Pathmarajah S., Thushyanthy M., Vithanage M. 2014. Seasonal variation of nitrate- $\mathrm{N}$ in groundwater: A case study from Chunnakam aquifer, Jaffna Peninsula. Ceylon Journal of Science (Physical Sciences). Vol. 18 p. 01-08.

ThadChayini T., ThiRUChelvam S. 2005. An economic evaluation of drip irrigation project for banana cultivation in Jaffna district. In: Water resources researches in Sri Lanka. Ed. L.G. Galagedara.. Symposium proceedings of the Water Professional's Day - 2005 p. 111-126.

USGS 2016. Water hardness [online]. The USGS Water Science School, U.S. Department of the Interior, U.S. Geological Survey. [Access 18.012017]. Available at: https://water.usgs. gov/edu/hardness.html

Verma A., Thakur B., Katiyar S., Singh D., Rai M. 2013. Evaluation of ground water quality in Lucknow, Uttar Pradesh using remote sensing and geographic information systems (GIS). International Journal of Water Resources and Environmental Engineering. Vol. 5. Iss. 2 p. 67-76.

Villholth K.G., RAJASOORIYAR L.D. 2010. Groundwater resources and management challenges in Sri Lanka - An overview. Water Resources Management. Vol. 24. Iss. 8 p. 14891513.

Vithanage M., Mikunthan T., Pathmarajah S., ArasalinGAM S., ManthrithiLAKE H. 2014. Assessment of nitrate-N contamination in the Chunnakam aquifer system, Jaffna Pen- 
insula, Sri Lanka. Springerplus. Vol. 3:271. DOI 10.1186/ 2193-1801-3-271.

WHO 1997. Guidelines for drinking-water quality. Vol. 3. Surveillance and control of community supplies. $2^{\text {nd }}$ ed. ISBN 92-4-154503-8 pp. 238.

WHO 2003a. State of the art of new vaccines research and development [online]. Geneva. World Health Organization. [Access 07.06.2016]. Available at: http://www.who.int/vaccine_ health/dwq/3tdvonki.pdf

WHO 2003b. Assessing microbial safety of drinking water improving approaches and methods: Improving approaches and methods [online]. Geneva. World Health Organization. ISBN 92-4-154630-1. [Access 24.02.2017]. Available at: www. who.int/water_sanitation_health/dwq/9241546301 full.pdf

WHO 2004. Guidelines for drinking water quality. Vol. 1. Recommendations. 3rd ed. Geneva. World Health Organization. ISBN 92-4-154638-7 pp. 494.

You Y., Rankin S.C., Aceto H.W., Benson C.E., Toth J.D., Dou Z. 2006. Survival of Salmonella enterica serovar Newport in manure and manure-amended soils. Applied and Environmental Microbiology. Vol. 72. Iss. 9 p. 5777-5783.

\section{M.G.Y.L. MAHAGAMAGE, Pavithrani S. MANAGE, Pathmalal M. MANAGE}

Jakość wody i mikrobiologiczne zanieczyszczenie wód gruntowych na półwyspie Jaffna na Sri Lance

\section{STRESZCZENIE}

Spośród 2588 przypadków zatrucia salmonellą zanotowanych na Sri Lance największą liczbę zachorowań stwierdzono na półwyspie Jaffna w latach 2005-2013. Dlatego prezentowane badania miały na celu identyfikację chemicznego i mikrobiologicznego zanieczyszczenia wód gruntowych z 40 studni w listopadzie 2016 r. Analizowano całkowitą liczbę bakterii z grupy coli, Escherichia coli, Salmonella spp., Shigella spp. oraz wybrane parametry fizyczne i chemiczne wód gruntowych. Wyniki ujawniły, że cały półwysep jest skażony bakteriami z grupy coli i bakterią Escherichia coli, a analizowane parametry nie spełniają standardów WHO i standardów Sri Lanki co do jakości wody. W 38\% badanych stanowisk stwierdzono obecność Salmonella spp., przy czym sześć z nich wykorzystywano jako źródła wody pitnej. Wyniki badań korelowały z rejestrowanymi przypadkami duru brzusznego na półwyspie. Stwierdzono także, że $80 \%$ studni nie spełniało wymogów stawianych wodzie pitnej przez normy Sri Lanki w odniesieniu do przewodnictwa elektrolitycznego. Ponadto stężenie azotanów w $15 \%$ studni było większe niż $10 \mathrm{mg} \cdot \mathrm{dm}^{-3}$, ale nie przekraczało granicznej wartości $45 \mathrm{mg} \cdot \mathrm{dm}^{-3} \mathrm{wyzna}-$ czonej przez normy dla wody pitnej. Analiza PCA wykazała, że miasto Jaffna oraz gminy Nallur, Tellippalai i Kopay mają wody o podobnych właściwościach.

Słowa kluczowe: bakterie z grupy coli, Escherichia coli, jakość wody, pótwysep Jaffna, Salmonella spp., Shigella spp., wody gruntowe 